\title{
TITLE:
}

\section{$<$ Book Info> Wild Cultures: A Comparison between Chimpanzee and Human Cultures}

AUTHOR(S):

\section{CITATION:}

<Book Info> Wild Cultures: A Comparison between Chimpanzee and Human Cultures. Pan Africa News 2012, 19(2): 28-28

ISSUE DATE:

2012-12

URL:

http://hdl.handle.net/2433/168175

\section{RIGHT:}

Copyright (C) Pan Africa News. 
2. Tutin CEG, Fernandez M 1984. Nationwide census of gorilla (Gorilla g. gorilla) and chimpanzee (Pan t. troglodytes) populations in Gabon. Am J Primatol 6:313-336.

3. Plumptre AJ, Reynolds V 1996. Censusing chimpanzees in the Budongo Forest, Uganda. Int J Primatol 17:85-99.

4. Ogawa H, Idani G, Moore J, Pintea L, Hernandez-Aguilar A 2007. Sleeping parties and nest distribution of chimpanzees in the savanna woodland, Ugalla, Tanzania. Int $J$ Primatol 28:1397-1412.

5. Stewart FA, Piel AK, McGrew WC 2011. Living archaeology: Artifacts of specific nest site fidelity in wild chimpanzees. J Hum Evol 61:388-395.

6. Ihobe H 2005. Life span of chimpanzee beds at the Mahale Mountains National Park, Tanzania. Pan Afr News 12:10-12.

7. Itoh $\mathrm{N}$, Nakamura $\mathrm{M}$, Ihobe $\mathrm{H}$, Uehara $\mathrm{S}$, Zamma $\mathrm{K}$, Pintea L, Seimon A, Nishida T 2012. Long-term changes in the social and natural environments surrounding the chimpanzees of the Mahale Mountains National Park. In: The Ecological Impact of Long-Term Changes in Africa's Rift Valley. Plumptre AJ (ed), NOVA Science, New York, pp. 249-277.

8. Nishida T 1972. A note on the ecology of the red-colobus monkeys (Colobus badius tephrosceles) living in the Mahali Mountains. Primates 13:57-64.

9. Nishida T, Uehara S 1981. Kitongwe name of plants: A preliminary listing. Afr Stud Monogr 1:109-131.

10. Sakamaki T, Nakamura M, Nishida T 2007. Evidence of cultural differences in diet between two neighboring unit groups of chimpanzees in Mahale Mountains National Park, Tanzania. Pan Afr News 14:3-5.

11. Takasaki H, Nishida T, Uehara S, Norikoshi K, Kawanaka K, Takahata Y, Hiraiwa-Hasegawa M, Hasegawa T, Hayaki H, Masui K, Huffman MA 1990. Summary of meteorological data at Mahale research camps, 1973-1988 In: The Chimpanzees of the Mahale Mountains: Sexual and Life History Strategies. Nishida T (ed), University of Tokyo Press, Tokyo, pp. 291-300.

\section{<BOOK INFO> \\ Wild Cultures: A Comparison between Chimpanzee and Human Cultures}

\section{By Christophe Boesch}

How do chimpanzees say, "I want to have sex with you?" By clipping a leaf or knocking on a tree trunk? How do they eat live aggressive ants? By using a short stick with one hand or long stick with both? Ivorian and Tanzanian chimpanzees answer these questions differently, as would humans from France and China if asked how they eat rice. Christophe Boesch takes readers into the lives of chimpanzees from different African regions, highlighting the debate about culture. His ethnography reveals how simple techniques have evolved into complex ones, how teaching styles differ, how material culture widens access to new food sources and how youngsters learn culture. This journey reveals many parallels between humans and chimpanzees and points to striking differences. Written in a vivid and accessible style, Wild Cultures places the reader in social and ecological contexts that shed light on our twin cultures.

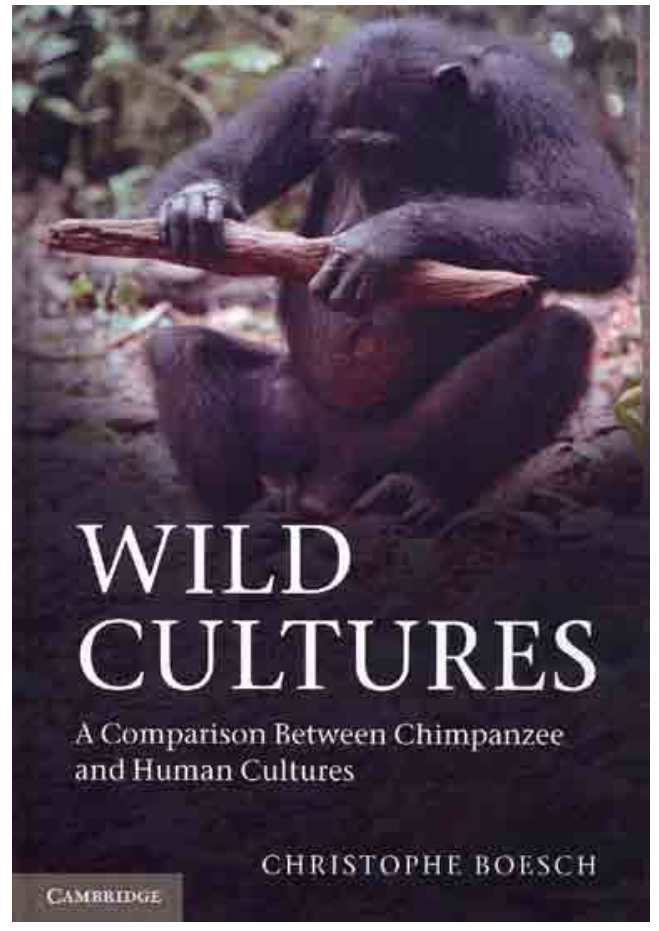

296 pages

Cambridge University Press

Publication date: September 2012

Hardcover $\$ 95.00$

ISBN: 9781107025370

\section{Contents}

Introduction

1. Studying culture in the wild

2. From human culture to wild culture

3. Shaping nature into home: about material culture

4. One for all and all for one: about social culture

5. I want to have sex with you: about symbolic culture

6. Learning culture: from pupils to teachers

7. Dead or alive? Towards a notion of death and empathy

8. Wild culture - wild intelligence

9. Uniquely chimpanzee - uniquely human

Epilogue: will we have the time to study chimpanzee culture?

References

Index

Pan Africa News, Vol. 19, No.2

Published in December, 2012

Address: c/o Human Evolution Studies,

Dept. of Zoology, Faculty of Science,

Kyoto Univ., Kyoto, 606-8502, JAPAN

TEL: $(+81) 75-753-4093$

FAX: $(+81) 75-753-4115$

E-mail: pan.editor@gmail.com

URL: http://mahale.main.jp/PAN/

ISSN: 1884-751X (Print), 1884-7528 (Online) 